\title{
Oncological wounds: meanings and emerging feelings of patients undergoing treatment
}

\author{
Abstract \\ Study design: Qualitative, exploratory, observational, transversal approach, with \\ intentional sampling. \\ Objectives: To know the meanings and feelings about the wounds, emerging from patients \\ on cancer treatment. \\ Methods: 30 patients with oncological wounds were interviewed using a semi-structured \\ interview instrument containing questions about the meaning and feelings of the patients \\ regarding their oncological wounds. The responses were analyzed through the Collective \\ Subject Discourse. Therefore final discourses were produced from reunion of patient's \\ speeches with the same central ideas. \\ Results: Substantial central ideas for cancer wound meaning were: "constant concern in my \\ life". Feeling about other people: "I'm worried", "I'm embarrassed". When it was asked \\ if the wounds influenced the relationship with their relatives: "yes, it took me away from \\ my family".
}

Conclusion: Patients present different meanings and feelings about their oncological wounds.
Volume 3 Issue 2 - 2019

\author{
Adriana Rodrigues dos Anjos Mendonça, \\ Thiago Marques Camargo, Sandiego Phelip \\ Sthefan Palhares, Taynan Bruno Ramos \\ Izidoro, Dênia Amélia Novato Castelli von \\ Atzingen \\ Sapucaí Valley University, Brazil
}

Correspondence: Adriana Rodrigues dos Anjos Mendonça, Professor at the Sapucaí Valley University, Pouso Alegre, Avenue Prefeito Tuany Toledo, 470, Fátima, Pouso Alegre, MG, zip code 37550-000, Brazil,Tel (35) 3449-92I I, Email drijar@hotmail.com

Received: December 12, 2018 | Published: April 03, 2019

Keywords: neoplasms, wounds and injuries, quality of life, oncology nursing

\section{Introduction}

Among patients with neoplasia 5 to $10 \%$ present the development of cutaneous metastasis. ${ }^{1}$ Neoplastic wounds constitute deformities, ulcerations in the most varied and most intrusive places, still bothering with their odors, bleeding and exudation, exposing oneself and others.

Neoplastic wounds are formed by the infiltration of malignant tumor cells into the skin structures. What is the energy of government and the origin of cell proliferation that triggers the production of induced oncogenesis, there is an exophytic wound. ${ }^{2}$

The formation of oncological wounds is linked to the growth of the tumor, which will cause the impact of the skin; a neovascularization, an important substrate for tumor growth and an invasion of the basal membrane of healthy cells, a process suitable for the expansive growth of the wound on the affected surface. ${ }^{2}$

Skin wounds affect people throughout the life cycle to recover tissue damage; the body using an intrinsic, dynamic, organized and complex biological process that can be rapid when a clinical activity is favorable and extensive in the degree of loss tissues are smaller. This fact causes a series of problems that affect the life of the individual in all its spheres, generating negative impact on the quality of life. ${ }^{3}$

Quality of life can be conditioned as a sensation of comfort, wellbeing or happiness, in the performance of their domains, intellectual and psychic within the reality of their family, their work and their values of community to quality. ${ }^{4}$ Interest in concepts such as "standard of living" and "quality of life" was initially shared by social media and philosophers. The next technological meeting in the area of health brought, as a consequence, the current situation and the prevalence of patient survival. ${ }^{5,6}$
Measurements of quality of sleep were generated and used, since the identification of problems as the general emotional state, social interaction, enabling the reduction of variables that can interfere in a negative way in the multidisciplinary follow-up of cancer patients. ${ }^{7}$

Oncology was the specialty that was confronted with the needs of evaluating the Quality of Life of its patients. ${ }^{8}$ The Quality of Life evaluation has been used within the health area as an important outcome in order to evaluate the impact of the disease felt by the patient, to create indicators of the severity and progression of the disease and to predict the influence of the treatments on the condition. ${ }^{9}$ Thus this research aims to know the meaning, for patients, of their oncological wounds and the implications of these wounds on the quality of life.

\section{Material and methods}

\section{Design and location of study}

A qualitative, exploratory, observational, cross-sectional study. Data collection was performed at the Samuel Libânio Clinical Hospital (HCSL), located in Pouso Alegre, MG. This hospital serves the population of 54 neighbouring municipalities.

\section{Participants and sample}

Thirty (30) patients with oncological wounds who attended the dressing room of the HCSL participated in the study. Sampling was intentional. The following inclusion criteria were used: patients older than 18 years, who had an oncological wound. As criteria of noninclusion: patient with other types of wound. Exclusion criteria: patient who gave up voluntary participation in the study, withdrawing their free and informed consent. 


\section{Data collection}

For data collection, a semi-structured interview script was used containing three questions:

a. Are oncological wounds constant concern in your life

b. What feelings arise when people look or perceive their wound?

c. If someone asked you if the neoplastic wound affects your relationship with family members, what would you say?

Before the interview, each patient was informed and clarified about the objectives of the study, signing the Informed Consent Term. The answers to the questions were recorded and later transcribed and analyzed using the Collective Subject Discourse method.

\section{Collective subject discourse method (DSC)}

The DSC is a methodological strategy with the purpose of clarifying a certain social representation and the set of representations that constitute an imaginary die. ${ }^{10}$ It consists in the meeting, in a single discourse-synthesis, of several individual discourses issued in response to the same question of research by social subject, and institutionally equivalent or that are part of the same organizational culture and of a homogeneous social group, insofar as the individuals who belong to this group occupy the same or neighbouring positions in a given social field. DSC is thus a way of directly expressing the social representation of a given subject. ${ }^{11}$

The DSC is written in the first person singular, composed of key expressions $(\mathrm{ECH})$ that of the speeches of participants who presented the same central ideas (IC) and the same anchorage (AC), obeying the order of the following steps:

1st stage: The answers were heard several times, and only after a better understanding of the general idea and the discourse is it was transcribed literally.

2nd stage: Total reading of the answers of each of the interviewees, followed by a separate reading of all the answers to the analyzed question.

3rd stage: Transcription of the answers to question 1, with the ECH in italics, and the CIs, which represent the description of the ECHs and not their interpretation, were marked.

4th stage: Individual transcription of each central idea with its respective $\mathrm{ECH}$.

5th stage: Extraction of the theme from each of the questions, grouping with their respective CI, the subjects, represented by the number of interviewed, and the frequencies of ideas through tables. Finally, construction of DSCs separately from each central idea, with their respective $\mathrm{ECH}$.

The study complied with the criteria required by Resolution $466 / 12$ of the National Health Council, and the project was previously approved by the Ethics Committee of the Sapucaí Valley University, under the opinion 393.830 of 09/14/2013.

\section{Results}

With regard to the first question: "Are oncological wounds a constant concern in your life?", 3 central ideas (CIs) have been identified: a. DO NOT KNOW IF THE WOUND IS A CONSTANT CONCERN IN MY LIFE;

b. WOUND IS A BIG CONCERN IN MY LIFE;

\section{c. IN SOME WAY THE WOUND IS A CONSTANT CONCERN IN MY LIFE}

Second question: "What feelings arise when people look or perceive their wound?", 7 ICs were observed:

a. I DO NOT CARE WHEN PEOPLE LOOK AT MY WOUND;

b. WHEN PEOPLE LOOK AT MY WOUND, THIS MAKES ME HAPPY;

c. I FEEL WORRIED, WITHOUT BEING WHEN PEOPLE LOOK AT MY WOUND;

d. FICO ENVERGONHADO WHEN PEOPLE LOOK AT MY WOUND;

e. I FEEL NUDE WHEN PEOPLE LOOK AT MY WOUND;

f. I DO NOT FEEL SICK WHEN PEOPLE LOOK AT MY WOUND;

g. I'M SAD AS THE PEOPLE LOOK AT MY WOUND.

Third question: "If someone asked you if the neoplastic wound affects your relationship with family members, what would you say?", 3 ICs were found:

a. THE WOUND DOES NOT AFFECT AT ALL MY RELATIONSHIP WITH MY FAMILIARS;

b. THE WOUND DISTANCED MY RELATIONSHIP WITH MY FAMILIARS;

c. I DO NOT KNOW MY RELATIONSHIP WITH MY FAMILIARS.

\section{Discussion}

The body is a reflection of society, and it is not possible to conceive processes exclusively biological, instrumental or aesthetic in human behavior. The body applies feelings, discourses and practices that are the basis of life in society. In turn, the body is emblematic of social processes. $^{12}$

Some discourses of the collective subject (DSC) obtained highlight this discussion:

"We do not get this problem because I've never had it. We have never seen each other and now, suddenly, this little thing comes out in me. I'm afraid to get this injury here and not fade, not heal. Well, it bothers, because soon another wound comes out, and she has to do another surgery ...."

“...the injury is releasing a little water, blood, it gets wet shirt, burning, and has to pass a cloth or paper. She bothers. It hurts too much and is too bloated. Therefore, I am afraid of dying of cancer"

The French philosopher and psychologist Michael Foucault, in his book "The Birth of the Clinic", discusses how the body, being a space of disease, becomes a text capable of different readings in search of meanings both for the patient in the process of unchaining symptoms, as for the clinician, when he pursues signs, signs, when examining 
the body of the other, the patient, and thus finds the visible forms of disease. ${ }^{13}$

The integrative vision between being and body, shown by Foucault, susceptible of different readings, significantly influences the quality of life. Its influence can be both positively and negatively depending on how the patient sees his or her reality. The rupture of the physical integrity of the body through the manifestation of the neoplastic wound and its subsequent biopsychosocial decharacterization is associated with the cultural and functional aspects of the body in our society. It is not the approach focused on cancer wound, but the person carrying the injury. And this approach comprises the physical, psychological, social and spiritual dimensions. ${ }^{14}$

"It's worrying. But, people are accustomed, right? I'm more than there. If I was younger I worried more"

The externalized tumor lesion causes a change in the patient's image, which depresses their self-esteem and makes it difficult to perform everyday tasks. Oncological wounds affect patients also because they have a continuous view of their clinical condition, because they still know that their appearance may mean ineffective treatment, incurable disease progression, or even the end of life..$^{15}$

At the same time, most patients are stigmatized, isolated and emotionally shaken, considerably reducing the chances and prospects of living together in a dignified manner in society. ${ }^{16}$

"In the beginning, my ex-wife started calling me cancerous, my face would turn into a monster. I was afraid after I became defective, I cried and just listening to her speak. That's when I tried suicide"

"Yeah, with my family a little. Because they, I do not know, seem to pity. With my sister and my children, it has messed up a bit, and I'm kind of like that, I do not play with them like I used to. I get a little away from them. There are people who have prejudice, who do not go near us, who cannot mix with us"

In the daily life of people with wounds there is suffering, and this happens due to doubts and anguishes about the treatment and, mainly, the anxiety in seeing the evolution of the wound for an improvement. From this perspective, it can be seen that for these people a wound may not only be a physical injury, but something that hurts without necessarily needing sensory stimuli, a mark, an irreparable loss, that is, something beyond an incurable disease. It weakens and often incapacitates the human being for various activities, especially those of labor. ${ }^{17}$

"The little girl messes up, sometimes I think about doing more things, and it comes at a time when I cannot do more things for my children or myself, it bothers me to sit down. I just want to take her"

Satisfy health needs goes back to several interpretations. What can be quality for a given population may be non-quality in other sectors of the population, the coverage of the needs of individuals and the degree of satisfaction that this coverage reaches among individuals. This thinking leads us to a broader view of quality, which depends not only on the type of activity, how it is performed and the resources available, but the subjectivity of how the recipient, that is, the population receiving it, will assess the quality of that activity health service. ${ }^{18-20}$

\section{Conclusion}

The patients participating in the research present different feelings and meanings regarding oncological wounds.

\section{Acknowledgments}

Foundation for Research Support of the State of Minas Gerais for the granting of the Scientific Initiation Grant (Probic Fapemig).

\section{Conflicts of interest}

The authors declare there is no conflict of interest.

\section{References}

1. Poletti NAAP, Caliri MHL, Simão CDSR, et al. Fungating wounds: a review of the literatura. Rev Bras Câncer. 2002;48(3):411-417.

2. Haisfield-Wolfe ME, Baxendale-Cox LM. Staging of malignant cutaneous wounds; a pilot study. Oncol Nur Forum. 1999;26(6):1055-1064.

3. http://www.scielo.br/scielo.php?script=sci_arttext\&pi$\mathrm{d}=\mathrm{S} 0080-62342009000500015$

4. Miettinem OS. Quality of life from the epidemiologic perspective. $J$ Chron Dis. 1987;40(6):641-643.

5. Mosconi P, Colozza M, De Laurentiis M, et al. Survival, quality of life and breast cancer. Ann Oncol. 2001;12 Suppl 3:S15-S19.

6. https://bdpi.usp.br/item/001220167

7. Amiel P, Dauchy S, Bodin J. Evaluating beauty care provided by the hospital to women suffering from breast cancer: qualitative aspects. Support Care Cancer. 2009;17(7):839-845.

8. http://www1.inca.gov.br/rbc/n_49/v04/pdf/revisao1.pdf

9. Berzon RA. Understanding and using health-related quality of life instruments within clinical research studies. In: Staquet MJ, Hays RD, Fayers PM, editors. Quality of life assessment in clinical trials: methods and practice. Oxford: Oxford University Press; 1998:3-15.

10. http://www.scielo.br/scielo.php?pid=S1413-81232008000400021\&scri $\mathrm{pt}=\mathrm{sci}$ abstract\&tlng $=\mathrm{pt}$

11. Lefévre L, Lefévre AMC. Os novos instrumentos no contexto da pesquisa qualitativa. In: Lefévre F, Lefévre AMC, Teixeira JJV, editors. $O$ discurso do sujeito coletivo: uma nova abordagem metodológica em pesquisa qualitativa. Caxias do Sul: EDUCS; 2000:11-35.

12. Alves PC, Minayo MCS. Saúde e doença: um olhar antropológico. Rio de Janeiro: Editora FIOCRUZ; 1994:174.

13. https:/edisciplinas.usp.br/pluginfile.php/4325478/mod resource/content/1/FOUCAULT_M_O_Nascimento_da_Cl_237_nica.pdf

14. https://www.santacasasp.org.br/upSrv01/up publicacoes/8011/10577 Manual\%20de\%20Cuidados\%20Paliativos.pdf

15. Bauer C, Gerlach MA, Doughty D. Care of metastatic skin lesions. $J$ Wound Ostomy Continence Nurs. 2000;27(4):247-251.

16. Ferreira AM, Candido MCFS, Pena SB. O cuidar de clientes com feridas: subsídios para a prática de enfermagem. Rev Mosaico UNIFEV. $2006 ; 1: 45-50$

17. Lucas LS, Martins JT, Robazzi MLCC. Qualidade de vida dos portadores de feridas em membros inferiores-úlcera de perna. Cienc Enferm. 2008;14(1):43-52.

18. Montesinos MJL. Programa de gestão da qualidade assistencial: uma oportunidade de melhoria no procedimento de curativos. In: Malagutti W, Kakihara CT, editors. Curativos, estomias e dermatologia: Uma abordagem multiprofissional. São Paulo: Martinari; 2010;13:201-221.

19. http://dms.ufpel.edu.br/ares/handle/123456789/224?show=full

20. Upright CA, Salton C, Roberts F, et al. Evaluation of mesalt dressing and continuous wet saline dressings in ulcerating metastatic skin lesions. Cancer Nurs. 1994;17(2):149-155. 